\title{
Photochemical production of dissolved inorganic nitrogen and primary amines from dissolved organic nitrogen in waters of two estuaries and adjacent surficial groundwaters
}

\author{
Dirk J. Koopmans ${ }^{1}$, Deborah A. Bronk ${ }^{2, *}$ \\ ${ }^{1}$ Department of Marine Sciences, University of Georgia, Athens, Georgia 30602-3636, USA \\ ${ }^{2}$ Virginia Institute of Marine Science, College of William and Mary, Gloucester Point, Virginia 23062-1346, USA
}

\begin{abstract}
Recent studies have shown that in a number of humic-rich surface waters in North America, $\mathrm{NH}_{4}{ }^{+}$is released when dissolved organic matter (DOM) is exposed to sunlight. However, photochemical $\mathrm{NH}_{4}{ }^{+}$production has not been observed in all surface waters, and factors that contribute to it are not well understood. We hypothesized that the presence or absence of $\mathrm{NH}_{4}{ }^{+}$photoproduction may be affected by the light exposure history of DOM. The present study was undertaken to determine whether DOM from surficial groundwaters, with minimal light exposure history, would produce labile nitrogen $(\mathrm{N})$ photoproducts more consistently. In this study, estuarine surface waters and surficial groundwaters, collected just adjacent to estuaries in Georgia and South Carolina, USA, were exposed to sunlight to quantify the photochemical production of $\mathrm{NH}_{4}{ }^{+}$, dissolved primary amines (DPA), and $\mathrm{NO}_{2}{ }^{-}$. The photoproduction of $\mathrm{NH}_{4}{ }^{+}$was observed in 4 of 5 irradiated estuarine surface water samples but in only 2 of 13 groundwater samples. In contrast, $\mathrm{NH}_{4}{ }^{+}$concentrations decreased in 5 of 13 groundwater samples when exposed to sunlight. The results indicate that a small amount of $\mathrm{NH}_{4}{ }^{+}$may be lost from waters in which groundwater-derived DOM is first exposed to sunlight. No consistent trends were observed in the photoproduction or loss of DPA and $\mathrm{NO}_{2}^{-}$.
\end{abstract}

KEY WORDS: UV radiation · Dissolved organic nitrogen · Groundwater · Ammonium · Dissolved primary amines $\cdot$ Nitrite

\section{INTRODUCTION}

Dissolved organic nitrogen (DON) accounts for 40 to $90 \%$ of the nitrogen $(\mathrm{N})$ in rivers of the southeastern United States (Alberts \& Takács 1999). Recent research has shown that microbes can utilize estuarine DON at rates that suggest it is a significant source of bioavailable $\mathrm{N}$ to estuaries and the coastal ocean (Seitzinger \& Sanders 1997; reviewed in Bronk 2002). One process that may contribute to the bioavailability of riverine DON is photochemical decomposition. Photochemical processes have been shown to result in the release of ammonium $\left(\mathrm{NH}_{4}{ }^{+}\right)$, dissolved primary amines (DPA), nitrite $\left(\mathrm{NO}_{2}{ }^{-}\right)$, and unidentified labile $\mathrm{N}$ compounds

${ }^{*}$ Corresponding author. E-mail: bronk@vims.edu when more refractory DON compounds are exposed to sunlight (Bushaw et al. 1996, Bushaw-Newton \& Moran 1999, Kieber et al. 1999, reviewed in Moran \& Zepp 1997). Of these, the observed rates of photoproduction of $\mathrm{NH}_{4}^{+}$are generally the greatest, between 0.04 and $0.4 \mu \mathrm{M} \mathrm{h}^{-1}$ (Bushaw et al. 1996, Gao \& Zepp 1998, Gardner et al. 1998). This production occurs at a wide range of sites rich in humic substances, including boreal ponds in Manitoba, a swamp and estuary in Georgia (Bushaw et al. 1996, Gao \& Zepp 1998), a river and bayou in Louisiana (Wang et al. 2000), and a humic-rich lake in Venezuela (Gardner et al. 1998). However, photochemical release of labile $\mathrm{N}$ is not always observed. For example, no $\mathrm{NH}_{4}{ }^{+}$release was observed during the irradiation of river, lake, and groundwater samples from boreal catchments in Sweden (Jørgensen et al. 1998, Bertilsson et al. 1999). 
The propensity for dissolved organic matter (DOM) to release $\mathrm{N}$ photoproducts is likely dependent on the source of the DOM. An additional factor that may contribute to the variability observed in photoproduction is light exposure history. For example, surface water DOM collected from stratified lakes and slow moving estuaries during the dry season would presumably have had a long exposure to light. In contrast, DOM collected from low order streams and ponds during a wet season would likely have experienced a shorter exposure time to light. These differences in light exposure, as well as variability in DOM source, likely contribute to the variability observed in the photoproduction of $\mathrm{NH}_{4}{ }^{+}$and DPA in different studies (Bushaw et al. 1996, Bertilsson et al. 1999, BushawNewton \& Moran 1999).

A source of DON that has received little attention in photoproduction studies, with the exception of Bertilsson et al. (1999), is groundwater. In surficial groundwaters, DOM is leached from overlying soils, vegetation, and anthropogenic sources. In surficial groundwaters in the southeastern United States, DON concentrations have been studied only rarely, but dissolved organic carbon (DOC) concentrations are generally 400 to $800 \mu \mathrm{MC}$ (Thurman 1985). As a rough extrapolation, even if the average atomic $\mathrm{C}: \mathrm{N}$ ratio of this DOM were high at 40:1 (i.e., Satilla River humic substances; Alberts \& Filip 1994), there would be between 10 and $20 \mu \mathrm{M}$ DON present in this groundwater. We hypothesized that groundwater-derived DON may play a proportionally greater role in the photoproduction of labile $\mathrm{N}$ because of its limited exposure to sunlight.

In this study, the photoproduction of labile $\mathrm{N}\left(\mathrm{NH}_{4}{ }^{+}\right.$, DPA, and $\mathrm{NO}_{2}{ }^{-}$) from DON collected from surficial groundwaters and from the epilimnion of estuaries was quantified. Groundwater samples were collected from residential and pristine sites in coastal Georgia and South Carolina and exposed to sunlight. To improve detection of photochemically produced labile $\mathrm{N}$, the
Fig. 1. Map of the South Atlantic Bight with 3 sampling sites: Site I, North Inlet, SC; Site II, Brunswick and St. Simon's Island, GA; Site III, Satilla River Estuary, GA

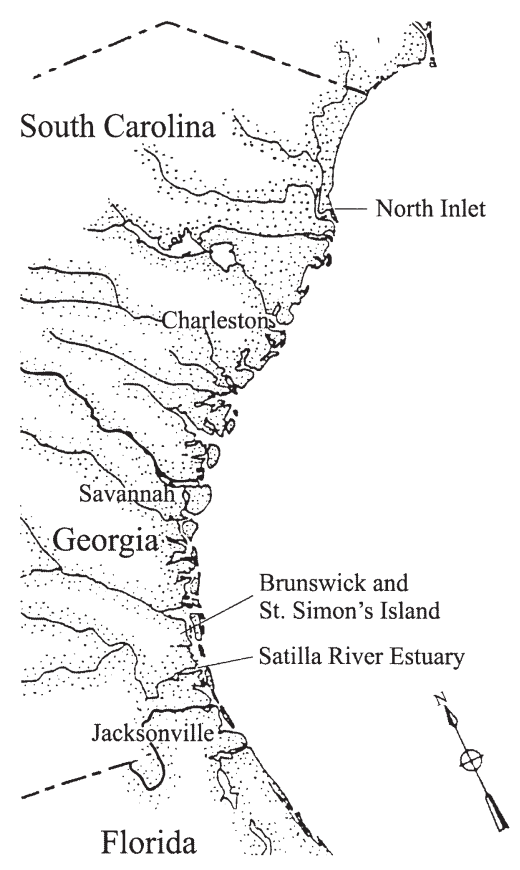

ratio of DON to dissolved inorganic nitrogen (DIN) was increased in a subset of surface water and groundwater samples collected from the Satilla River Estuary, which has been the focus of previous photochemical studies (Bushaw et al. 1996, Gao \& Zepp 1998).

\section{MATERIALS AND METHODS}

Surficial groundwater samples $(<10 \mathrm{~m}$ depth) were collected from 3 sites: North Inlet, South Carolina; Brunswick/St. Simon's Island, Georgia; and the Satilla River, Georgia. Water column samples were collected at North Inlet and the Satilla River sites (Fig. 1, Table 1).

Site I: North Inlet, South Carolina. North Inlet is a pristine estuary $90 \mathrm{~km}$ northeast of Charleston, South

Table 1. Summary of sites where groundwater and surface water samples were collected including the treatments used to increase the dissolved organic nitrogen (DON) to $\mathrm{NH}_{4}{ }^{+}$ratio of samples from Site III, and the light source used for irradiating samples

\begin{tabular}{|lcccc|}
\hline $\begin{array}{l}\text { Site no. and } \\
\text { location }\end{array}$ & $\begin{array}{c}\text { Sample } \\
\text { date }\end{array}$ & $\begin{array}{c}\text { Site } \\
\text { description }\end{array}$ & $\begin{array}{c}\text { Organic matter } \\
\text { treatments }\end{array}$ & $\begin{array}{c}\text { Light } \\
\text { source }\end{array}$ \\
\hline I. North Inlet, SC & Feb 1999 & $\begin{array}{c}\text { Spartina alterniflora } \\
\text { salt marsh } \\
\text { II. Brunswick and }\end{array}$ & $\begin{array}{c}\text { Suburban } \\
\text { communities }\end{array}$ & None \\
$\begin{array}{l}\text { St. Simon's, GA } \\
\begin{array}{l}\text { III. Satilla River } \\
\text { Estuary, GA }\end{array}\end{array}$ & $\begin{array}{c}\text { Sep 1999 } \\
\text { May 2000, }\end{array}$ & None & Sunlight \\
Jul 2000 & density, pine forests & $\begin{array}{c}\text { Rotary evaporation, } \\
\text { ultrafiltration }\end{array}$ & Xenon arc lamp \\
\hline
\end{tabular}


Carolina, surrounded by Spartina alterniflora salt marsh. Groundwater samples were collected in February 1999 from 5 polyvinyl chloride (PVC) groundwater monitoring wells (1.2 to $2.4 \mathrm{~m}$ deep): 2 in an upland pine forest, 1 mid-marsh, and 2 in the marsh edge on the bank of a tidal creek. The marsh wells drew water from a layer of sand beneath the marsh mud. Approximately $10 \mathrm{l}$ of water was removed and discarded from each well before $1.5 \mathrm{l}$ of sample was collected. One water column sample was also collected from just below the surface $(<0.5 \mathrm{~m}$ depth) of Town Creek, a creek that drains the study area. Within $7 \mathrm{~h}$ after collection, the samples were filtered through a precombusted $\left(500^{\circ} \mathrm{C}\right.$ for $2 \mathrm{~h}$ ) GF/F filter (nominal cutoff of $0.7 \mu \mathrm{m})$ and a Supor filter $(0.2 \mu \mathrm{m}$ cutoff). All groundwater samples collected in this study were initially sulfidic. Oxygen was reintroduced to groundwaters prior to photooxidation by gently shaking samples in bottles with headspace. The samples were stored at $4^{\circ} \mathrm{C}$ until photooxidized.

Site II: Brunswick and St. Simon's Island, Georgia. Brunswick is a town of approximately 17000 inhabitants, $100 \mathrm{~km}$ south of Savannah, Georgia. St. Simon's Island is adjacent to Brunswick and has been developed primarily for vacation homes. Groundwater was collected from 1 PVC-lined residential well (the well screen depth was approximately 3 to $5 \mathrm{~m}$ ) in a suburban community in Brunswick and 3 similar wells on St. Simon's Island in September 1999. The surficial aquifer in this area extends to $>40 \mathrm{~m}$ depth (Clarke et al. 1990), so all the groundwater collected was from this surficial aquifer. Water was pumped from the wells until temperature and dissolved oxygen readings stabilized (over $20 \mathrm{l}$ of water was discarded) before collecting samples. Each sample was stored on ice for up to $2 \mathrm{wk}$ until they were filtered through GF/F and Supor filters and photooxidized.

Site III: Satilla River Estuary, Georgia. The Satilla River is a 'black water' river that receives DOM from extensive swamps in the drainage area of Georgia's coastal plain. Two groundwater and 2 water column samples were collected from the Satilla River Estuary during the summer of 2000. Groundwater samples were drawn from surficial aquifers $(1.5 \mathrm{~m}$ depth) through a stainless steel well point sampler (Valiela \& Costa 1988), 20 m or less from Umbrella Creek, a tidal creek that drains into the Satilla River Estuary. Water column samples were collected just below the water surface $(<0.5 \mathrm{~m})$ in May 2000 from the head of the estuary (non-saline) and from Umbrella Creek (salinity of 25 parts per thousand). The surface and groundwater samples were filtered within $14 \mathrm{~h}$ of collection through $\mathrm{GF} / \mathrm{F}$ and Supor filters and stored at $4^{\circ} \mathrm{C}$ until subdivision into fractions for photooxidation pre-treatments 1 to 2 wk later.
Treatments of Site III samples prior to photooxidation. To improve the detection of photochemically produced $\mathrm{NH}_{4}{ }^{+}$, rotary evaporation and tangential flow ultrafiltration were used to increase the concentration of DON relative to the background concentration of $\mathrm{NH}_{4}{ }^{+}$, which was greater than $20 \mu \mathrm{M}$ in some groundwater samples. In the rotary evaporation treatment, 11 of sample was brought to $\mathrm{pH} 9.5$ and rotary evaporated (Büchi Rotavapor R110, Büchi Analytical Ltd, Manchester, UK) at a vacuum of $71 \mathrm{~cm} \mathrm{Hg}$ at room temperature for $45 \mathrm{~min}$. The change in $\mathrm{pH}$ resulted in the conversion of ambient $\mathrm{NH}_{4}{ }^{+}$to volatile ammonia $\left(\mathrm{NH}_{3}\right)$ gas and the loss of $\mathrm{NH}_{3}$ during evaporation. As a result, the background $\mathrm{NH}_{4}{ }^{+}$concentration, which might obscure a small amount of photoproduction, was reduced. Immediately following rotary evaporation, the sample was diluted to its original volume with deionized water and acidified to the original $\mathrm{pH}$. The volumes of the rotary evaporated Satilla River surface water, Umbrella Creek surface water, and Umbrella groundwater (GW-A; replicate samples are designated A, B or C) samples were diluted an additional 10 to $14 \%$ to provide sufficient sample volume for the analyses. All rotary evaporated samples were gently shaken and then stored with headspace for at least $24 \mathrm{~h}$ to allow oxygen to dissolve into solution.

In the tangential flow ultrafiltration treatment, $10 \mathrm{l}$ of the unmanipulated sample from each site was filtered through a series of two $1 \mathrm{kDa}$ molecular weight cut off cellulose acetate ultrafiltration membranes (Millipore) using a DC10L tangential flow ultrafiltration unit (Amicon Inc, Beverly, MA, USA). Before the sample was ultrafiltered, the membranes were cleaned with 201 of $0.2 \mathrm{~N} \mathrm{NaOH}$ and rinsed with 60 to $80 \mathrm{l}$ of deionized water. The sample was brought to $\mathrm{pH} 7$ and forced across the 2 membranes, at inlet and outlet pressures of $3.5 \mathrm{~kg} \mathrm{~cm}{ }^{2}$. The volume of the retentate, containing the fraction of the DON that did not pass through the membranes, was brought to one-third the initial sample volume. Then the outlet pressure was briefly reduced to $0.4 \mathrm{~kg} \mathrm{~cm}^{2}$ to improve recovery of DOM adsorbed to the membranes, as recommended by Benner et al. (1997). The retentate was brought back to the original $\mathrm{pH}$ and stored at $4^{\circ} \mathrm{C}$ for later photooxidation experiments. The permeate, the fraction of the DON that passed through the membrane, was discarded because the concentration of DON was low (approximately $5 \mu \mathrm{M}$ ) such that detecting photoproduction of labile $\mathrm{N}$ from it would have been unlikely.

Photooxidation of samples. To reduce the number of bacteria in irradiated and control samples and to minimize microbial uptake of photoproducts, all samples from Sites I, II, and III were filtered through GF/F and $0.2 \mu \mathrm{m}$ Supor filters and stored at $4^{\circ} \mathrm{C}$ until they were 
exposed to artificial sunlight. Samples from Sites I and II were GF/F and $0.2 \mu \mathrm{m}$ Supor filtered only once, 24 to $80 \mathrm{~h}$ before photooxidation, to minimize the possibility of introducing DON artifacts of filtration. Samples from Site III were GF/F and $0.2 \mu \mathrm{m}$ Supor filtered twice, immediately after collection and again 20 to $40 \mathrm{~h}$ before photooxidation, to reduce bacterial regrowth that may have occurred during rotary evaporation and ultrafiltration. Each sample was poured into 6 quartz tubes, 3 of which were wrapped in aluminum foil as experimental controls. The experimental and control tubes of samples from Sites I and II were placed in a cool water bath $\left(10\right.$ to $\left.15^{\circ} \mathrm{C}\right)$ and exposed to sunlight in Athens, Georgia (latitude $34^{\circ} \mathrm{N}$ ) for 5 to $10 \mathrm{~h}$. The experimental and control tubes from Site III were placed in adjacent cold water baths and exposed to $8 \mathrm{~h}$ of artificial sunlight at an intensity of $1000 \mu \mathrm{E} \mathrm{m}{ }^{-2} \mathrm{~s}^{-1}$ generated by a xenon arc lamp (Suntest CPS solar simulator, Atlas Electric Devices, Chicago, IL, USA). The spectrum of UV irradiance had been adjusted to closely match midday sunlight in June in Athens, Georgia. The heat of the lamp brought the temperatures of both water baths from 5 to $10^{\circ} \mathrm{C}$. Following irradiation the samples were subdivided and frozen for $\mathrm{NH}_{4}{ }^{+}, \mathrm{NO}_{2}{ }^{-}$, and DPA analyses. The absorbance of samples from Site III, before and after irradiation, was determined at a wavelength of $350 \mathrm{~nm}$ by a Beckman DU 640 spectrophotometer.

Chemical analyses. For irradiated and control treatments, the reported nutrient concentrations are the means of triplicate analyses performed on each of the 3 control and irradiated experimental replicates. Ammonium was analyzed spectrophotometrically by the manual phenol-hypochlorite method, which responds negligibly to amino acids (Koroleff 1983, detection limit $0.05 \mu \mathrm{M}$ ). Nitrite concentrations in waters from Sites I and III were measured by the chemiluminescent method (Garside 1982; detection limit of $0.1 \mu \mathrm{M}$ ). Nitrite concentrations in waters from Site II were determined by the colorimetric method (Grasshoff 1983; detection limit of $0.25 \mu \mathrm{M}$ in highly colored water). Concentrations of DPA were measured spectrofluorometrically (Parsons et al. 1984); DPA concentrations were reported as glycine equivalents after correction for the fluorescence of ambient $\mathrm{NH}_{4}{ }^{+}$ (Liebezeit \& Behrends 1999). Samples for DOC analyses were acidified to $\mathrm{pH} \mathrm{3}$, sparged for $15 \mathrm{~min}$ with carbon-free air, and analyzed using a Shimadzu TOC-5000 (Moran et al. 1999).

The concentration of DON was determined by subtracting the concentration of DIN $\left(\mathrm{NO}_{3}^{-}, \mathrm{NO}_{2}{ }^{-}\right.$, and $\mathrm{NH}_{4}{ }^{+}$) from the concentration of total dissolved nitrogen (TDN) determined by persulfate oxidation (Bronk et al. 2000). The humic-N and $\mathrm{C}$ concentrations were determined by humic adsorption to Supelite DAX-8 macroporous resin (the current replacement for
Amberlite XAD-8, Supelco, Belleforte, Pennsylvania; Aiken 1985).

Data analyses. The concentrations of a given compound determined in the 3 irradiated replicates were compared to the concentrations in the corresponding controls with a 2-tailed Student's t-test $(\alpha=0.05)$. Equal variance was assumed for irradiated and control concentrations. When the mean concentration of a constituent in the irradiated water was significantly greater than the mean concentration in the controls $(p \leq 0.05)$, the difference was interpreted as photoproduction. When the reverse was true, the difference was interpreted as a photochemically mediated loss.

Rate normalization. To compare the net rates of $\mathrm{NH}_{4}{ }^{+}$ photoproduction between samples and treatments, rates were normalized to DON concentrations by dividing the $\mathrm{NH}_{4}{ }^{+}$production rate by the initial DON concentration in the sample. For Site III, $\mathrm{NH}_{4}{ }^{+}$photoproduction was normalized to absorbance by dividing net production rates by the sample absorption coefficient at $350 \mathrm{~nm}\left(\mathrm{a}_{350}\right)$, defined as $2.303 \times A_{350} / b$, where $A_{350}$ is the measured absorbance at $350 \mathrm{~nm}$ and $b$ is the path length of light through the sample in meters (Miller \& Zepp 1995). Photoproduction rates were corrected for self-shading at $350 \mathrm{~nm}$ by a light screening factor calculated using the derivation of a formula presented by Zepp (1982) given in Bushaw-Newton \& Moran (1999): $\left(1-\mathrm{e}^{-\mathrm{a}_{350} \times b}\right) /\left(\mathrm{a}_{350} \times b\right)$, where $b$ is the average pathlength of light through the irradiation vessel in meters ( $0.009 \mathrm{~m}$ in this study). This is a correction factor for the amount of light attenuated within a sample by DOM.

\section{RESULTS}

Water samples collected from 2 tidal creeks, the Satilla River, and shallow groundwaters were exposed to natural or artificial sunlight to examine photoproduction of labile $\mathrm{N}$. The initial DIN and DON concentrations and the effect of irradiation on $\mathrm{NH}_{4}{ }^{+}, \mathrm{NO}_{2}{ }^{-}$, and DPA concentrations are presented below.

\section{Inorganic and organic $\mathbf{N}$ concentrations}

In surface water samples, most of the dissolved N (77 to $97 \%$ ) was organic in nature. In the Satilla River and Umbrella Creek, most of that organic N (83 and 63\%, respectively) was associated with humic substances (Table 2). The predominant forms of DIN were $\mathrm{NO}_{3}{ }^{-}$in the Satilla River and $\mathrm{NH}_{4}{ }^{+}$in Umbrella and Town Creeks. In contrast, most of the dissolved $\mathrm{N}$ in groundwater samples was inorganic, specifically $\mathrm{NH}_{4}{ }^{+}$. About $80 \%$ of the dissolved $\mathrm{N}$ in Marsh Creek GW-A and B samples and the Brunswick GW sample was $\mathrm{NH}_{4}{ }^{+}$. In 
Table 2. Concentration of dissolved organic nitrogen (DON; mean $\pm \mathrm{SD}$ ), percentage of DON eluted with humic substances, the dissolved organic carbon to DON (C:N) ratio, and the absorptivity of surface and groundwater samples. Concentrations were determined immediately before the samples were photooxidized, except where noted. See Table 1 for site definitions. Two treatments were used at Site III: $\mathrm{NH}_{4}{ }^{+}$was removed by rotary evaporation (RE) or DON was concentrated with ultrafiltration (UF). GW: groundwater; $\mathrm{a}_{350}$ : absorption coefficient at $350 \mathrm{~nm}$; na: not available. Replicate samples taken from the same location are designated by A, B or C

\begin{tabular}{|lrccc|}
\hline Site no. and sample & $\begin{array}{c}\text { DON } \\
(\mu \mathrm{M} \mathrm{N})\end{array}$ & $\begin{array}{c}\% \text { DON in } \\
\text { humic-N }\end{array}$ & C:N & $\begin{array}{c}\mathrm{a}_{350} \\
\left(\mathrm{~m}^{-1}\right)\end{array}$ \\
\hline Surface water & & & & \\
I. Town Creek & $12 \pm 0.9$ & 65 & na & na \\
III. Satilla River (RE) & $37 \pm 0.8$ & $83^{\mathrm{a}}$ & 39 & 43.8 \\
III. Satilla River (UF) & $107 \pm 1.1$ & na & 38 & 128 \\
III. Umbrella Creek (RE) & $22 \pm 0.5$ & $63^{\mathrm{a}}$ & 23 & 9.1 \\
III. Umbrella Creek (UF) & $50 \pm 1.3$ & na & 25 & 21.2 \\
Shallow groundwater & & & & \\
I. Upland GW-A & $27 \pm 1.0$ & 57 & na & na \\
I. Upland GW-B & $64 \pm 1.6$ & 66 & na & na \\
I. Marsh GW & $16 \pm 1.7$ & $>90$ & na & na \\
I. Creek GW-A & $1.9 \pm 2.6$ & $>90$ & na & na \\
I. Creek GW-B & $12 \pm 0.9$ & 54 & na & na \\
II. Brunswick GW & $1 \pm 0.1$ & 54 & 56 & na \\
II. St. Simon's GW-A & $35 \pm 0.9$ & 57 & 43 & na \\
II. St. Simon's GW-B & $14 \pm 0.8$ & 62 & 47 & na \\
II. St. Simon's GW-C & $21 \pm 0.5$ & 51 & 43 & na \\
III. Umbrella GW-A (RE) & $26 \pm 0.4$ & $71^{\mathrm{a}}$ & 46 & 21.8 \\
III. Umbrella GW-A (UF) & $67 \pm 1.8$ & na & 43 & 56.8 \\
III. Umbrella GW-B (RE) & $9 \pm 0.3$ & $63^{\mathrm{a}}$ & 74 & 3.7 \\
III. Umbrella GW-B (UF) & $25 \pm 3.3$ & na & 48 & 10.4 \\
aAnalysis performed before RE treatment & & & \\
& & & & \\
\hline
\end{tabular}

Table 3. Effect of rotary evaporation (RE) at pH 9.5 for 45 min on the concentration of $\mathrm{NH}_{4}{ }^{+}$and DON in surface and groundwater samples collected at Site III, the Satilla River Estuary. Following rotary evaporation the Satilla River, Umbrella Creek and Umbrella GW-A samples were diluted with deionized water (DI) to provide sufficient volume for photooxidation (Dilution with DI)

\begin{tabular}{|lccccc|}
\hline & $\begin{array}{c}\text { Initial } \mathrm{NH}_{4}{ }^{+} \\
(\mu \mathrm{M})\end{array}$ & $\begin{array}{c}\text { Final } \mathrm{NH}_{4}^{+} \\
(\mu \mathrm{M})\end{array}$ & $\begin{array}{c}\text { Initial DON } \\
(\mu \mathrm{M})\end{array}$ & $\begin{array}{c}\text { DON loss } \\
(\%)\end{array}$ & $\begin{array}{c}\text { Dilution } \\
\text { with DI } \\
(\%)\end{array}$ \\
\hline Satilla River & 0.33 & 0.26 & 46.4 & 6 & 14 \\
Umbrella Creek & 6.29 & 0.30 & 22.4 & 0 & 13 \\
Umbrella GW-A & 8.62 & 0.14 & 32.9 & 13 & 10 \\
Umbrella GW-B & 21.9 & 1.14 & 11.8 & 19 & 0 \\
\hline
\end{tabular}

\section{Effect of rotary evaporation and tangential flow ultrafiltration}

As a result of the rotary evaporation treatment, $\mathrm{NH}_{4}{ }^{+}$concentrations were reduced to low levels $(1.2$ to $0.1 \mu \mathrm{M})$, a reduction of up to $98 \%$ from ambient concentrations (Table 3). There was a concurrent loss of up to $19 \%$ of the DON during rotary evaporation, perhaps due to the volatilization of amine groups. The ultrafiltration treatment only slightly reduced the average $\mathrm{NH}_{4}{ }^{+}$ concentrations, while increasing the DON concentration approximately 2fold (Table 4). There was some loss of DON through the $1 \mathrm{kDa}$ membranes, but the overall retention was about $70 \%$. At less than a 10-fold concentration factor, tangential flow ultrafiltration may not completely separate high and low molecular weight (LMW) compounds (Benner et al. 1997), so a significant fraction of the retentate DON in these samples may have been LMW compounds. Concentrations of DOC, consistent with DON, increased 1.7- to 2.3-fold during ultrafiltration, with 60 to $75 \%$ of the DOC retained by the membranes (data not shown).

\section{Rates of photoproduction}

The photoproduction of $\mathrm{NH}_{4}{ }^{+}$was observed in river and creek samples. However, there was more photochemically mediated loss of $\mathrm{NH}_{4}{ }^{+}$ than production in the groundwater samples. Statistically significant $(t$ test, $\mathrm{p}<0.05)$ photoproduction of $\mathrm{NH}_{4}{ }^{+}$was observed in 4 of 5 surface water experiments (Table 5). In groundwaters from Sites I and II, the

all groundwater samples except Upland GW-B, St. Simon's GW-A and B, and Umbrella GW-A, over $50 \%$ of dissolved $\mathrm{N}$ was $\mathrm{NH}_{4}{ }^{+}$. The concentration of $\mathrm{NO}_{3}{ }^{-}$ was highest in the Brunswick GW sample, where it accounted for $18 \%$ of the dissolved N. In all other groundwater samples $\mathrm{NO}_{3}{ }^{-}$accounted for $3 \%$ or less of the N. Most of the DON in groundwater samples, similar to DON in surface waters, was associated with humic substances (Table 2). photochemically mediated loss of $\mathrm{NH}_{4}{ }^{+}$was observed in 3 of 9 irradiated samples $(\mathrm{p}<0.01)$, but photoproduction was observed in only 2 of 9 irradiated samples ( $\mathrm{p}<0.05$; Table 5$)$. No net photochemical production or loss of $\mathrm{NH}_{4}{ }^{+}$was observed in the rotary evaporation treatment of irradiated groundwater samples from Site III, but $\mathrm{NH}_{4}{ }^{+}$was lost from both ultrafiltration treatments of the same samples (p $<0.01$; Table 5). 
Table 4. Effect of tangential flow UF (1 kDa molecular weight cut-off membrane) on the retentate concentrations of $\mathrm{NH}_{4}{ }^{+}$and DON in samples from Site III, the Satilla River Estuary. Percentages of DON that passed through the UF membranes (permeate) and that were unaccounted for are also given

\begin{tabular}{|c|c|c|c|c|c|c|c|}
\hline Sample & $\begin{array}{l}\text { Initial } \\
\mathrm{NH}_{4}{ }^{+} \\
(\mu \mathrm{M})\end{array}$ & $\begin{array}{l}\text { Final } \\
\mathrm{NH}_{4}^{+} \\
(\mu \mathrm{M})\end{array}$ & $\begin{array}{l}\text { Initial } \\
\text { DON } \\
(\mu \mathrm{M})\end{array}$ & $\begin{array}{l}\text { DON } \\
\text { conc. } \\
\text { factor }\end{array}$ & $\begin{array}{c}\mathrm{DON} \text { in } \\
\text { retentate } \\
(\%)\end{array}$ & $\begin{array}{c}\mathrm{DON} \text { in } \\
\text { permeate } \\
(\%)\end{array}$ & $\begin{array}{c}\text { Missing } \\
\text { DON } \\
(\%)\end{array}$ \\
\hline Satilla River & 0.3 & 0.4 & 47.7 & 2.2 & 73 & 13 & 14 \\
\hline Umbrella Creek & 6.3 & 5.5 & 24.3 & 2.0 & 70 & 24 & 6 \\
\hline Umbrella GW-A & 8.6 & 7.7 & 31.2 & 2.2 & 76 & 16 & 8 \\
\hline Umbrella GW-B & 21.9 & 20.5 & 13.0 & 2.0 & 69 & 23 & 8 \\
\hline
\end{tabular}

Table 5. Mean $\mathrm{NH}_{4}{ }^{+}$concentrations $( \pm \mathrm{SD})$ in surface and groundwaters, unexposed to light (controls) and irradiated. Samples from Site III were RE at $\mathrm{pH} 9.5$ to reduce $\mathrm{NH}_{4}{ }^{+}$concentrations or concentrated by tangential flow UF before irradiation. P and L mark statistically significant production and loss of $\mathrm{NH}_{4}{ }^{+}$, respectively, in irradiated samples $(\alpha=0.05$, Student's $t$-test). The DON normalized (norm.) rate is the rate of photochemical $\mathrm{NH}_{4}{ }^{+}$production divided by the DON concentration. -: no significant change

\begin{tabular}{|c|c|c|c|c|}
\hline Site no. and sample & $\begin{array}{c}\text { Control } \\
\mathrm{NH}_{4}^{+}(\mu \mathrm{M})\end{array}$ & $\begin{array}{l}\text { Irradiated } \\
\mathrm{NH}_{4}^{+}(\mu \mathrm{M})\end{array}$ & $\begin{array}{l}\text { Production } \\
\text { or loss }\end{array}$ & $\begin{array}{c}\text { DON norm } \\
\times 10^{-3} \mathrm{~h}^{-1}\end{array}$ \\
\hline \multicolumn{5}{|l|}{ Surface water } \\
\hline I. Town Creek & $0.21 \pm 0.02$ & $0.45 \pm 0.02$ & $\mathrm{P}$ & $2.9 \pm 0.4$ \\
\hline III. Satilla River (RE) & $0.29 \pm 0.01$ & $0.44 \pm 0.02$ & $\mathrm{P}$ & $0.50 \pm 0.1$ \\
\hline III. Satilla River (UF) & $0.33 \pm 0.04$ & $0.44 \pm 0.03$ & $\mathrm{P}$ & $0.1 \pm 0.1$ \\
\hline III. Umbrella Creek (RE) & $0.41 \pm 0.11$ & $0.54 \pm 0.09$ & - & \\
\hline III. Umbrella Creek (UF) & $5.65 \pm 0.06$ & $5.88 \pm 0.08$ & $\mathrm{P}$ & $0.6 \pm 0.2$ \\
\hline \multicolumn{5}{|l|}{ Shallow groundwater } \\
\hline I. Upland GW-A & $26.08 \pm 0.12$ & $25.05 \pm 0.10$ & - & \\
\hline I. Upland GW-B & $27.89 \pm 0.05$ & $25.69 \pm 0.15$ & $\mathrm{~L}$ & $-4.9 \pm 0.4$ \\
\hline I. Marsh GW & $19.48 \pm 0.05$ & $19.50 \pm 0.09$ & - & \\
\hline I. Creek GW-A & $21.18 \pm 0.31$ & $20.53 \pm 0.07$ & - & \\
\hline I. Creek GW-B & $14.52 \pm 0.15$ & $14.96 \pm 0.15$ & $\mathrm{P}$ & $7.3 \pm 3.4$ \\
\hline II. Brunswick GW & $4.53 \pm 0.12$ & $4.68 \pm 0.11$ & - & \\
\hline II. St. Simon's GW-A & $18.93 \pm 0.14$ & $16.84 \pm 0.11$ & $\mathrm{~L}$ & $-6.4 \pm 0.5$ \\
\hline II. St. Simon's GW-B & $6.74 \pm 0.09$ & $7.91 \pm 0.05$ & $\mathrm{P}$ & $9.1 \pm 0.8$ \\
\hline II. St. Simon's GW-C & $30.11 \pm 0.11$ & $28.45 \pm 0.05$ & $\mathrm{~L}$ & $-8.1 \pm 0.6$ \\
\hline III. Umbrella GW-A (RE) & $0.42^{\mathrm{a}}$ & $0.54 \pm 0.08$ & - & \\
\hline III. Umbrella GW-A (UF) & $7.64 \pm 0.03$ & $7.29 \pm 0.06$ & $\mathrm{~L}$ & $-0.6 \pm 0.1$ \\
\hline III. Umbrella GW-B (RE) & $1.21 \pm 0.06$ & $1.30 \pm 0.07$ & - & \\
\hline III. Umbrella GW-B (UF) & $20.65 \pm 0.04$ & $20.49 \pm 0.04$ & $\mathrm{~L}$ & $-0.8 \pm 0.3$ \\
\hline${ }^{\mathrm{a}} \mathrm{n}=1$ & & & & \\
\hline
\end{tabular}

The DON-normalized rates of $\mathrm{NH}_{4}{ }^{+}$photoproduction and loss were greater among samples from Sites I and II than the manipulated samples from Site III (Table 5). The greatest DON-normalized rate of $\mathrm{NH}_{4}{ }^{+}$photoproduction in surface waters was observed in Town Creek, from Site I $\left(2.9 \times 10^{-3} \mathrm{~h}^{-1}\right)$. The DON-normalized rates of $\mathrm{NH}_{4}{ }^{+}$photochemical production observed in the 2 groundwater samples were $7.3 \times 10^{-3}$ and $9.1 \times 10^{-3} \mathrm{~h}^{-1}$. As in surface waters, the magnitude of DON-normalized rates of $\mathrm{NH}_{4}{ }^{+}$loss among groundwaters from Sites I and II $\left(-4.9 \times 10^{-3}\right.$ to $\left.-8.1 \times 10^{-3} \mathrm{~h}^{-1}\right)$ were greater than rates observed in manipulated samples (Table 5).

Few significant differences in DPA and $\mathrm{NO}_{2}^{-}$ concentrations between irradiated and control treat- ments were observed (Table 6). No statistically significant changes $(\mathrm{p}<0.05)$ in DPA concentrations were observed in irradiated water column samples. Among groundwaters, the photochemical production of DPA $(p<0.05)$ was observed in only 1 of 9 irradiated samples from Sites I and II. The photochemically mediated loss of DPA $(p<0.05)$ was observed in both rotary evaporation and ultrafiltration treatments of Umbrella Creek GW-A but not in GW-B. Normalized to the concentration of DON in the samples, DPA production and loss rates were low $\left(-1.6 \times 10^{-3},-0.6 \times 10^{-3}\right.$ and $1.3 \times 10^{-3} \mathrm{~h}^{-1}$ ) but comparable to rates of $\mathrm{NH}_{4}{ }^{+}$production and loss.

The photochemically mediated loss of $\mathrm{NO}_{2}^{-}(\mathrm{p}<$ 0.05) was observed in 1 of 4 treatments of surface 
Table 6. Mean dissolved primary amines (DPA) and $\mathrm{NO}_{2}{ }^{-}$concentrations $( \pm \mathrm{SD})$ in surface and groundwaters, unexposed to light (controls) and irradiated. Samples from Site III were RE at pH 9.5 to reduce $\mathrm{NH}_{4}{ }^{+}$concentrations or concentrated by tangential flow UF before irradiation. The DON normalized rates of photochemical DPA and $\mathrm{NO}_{2}{ }^{-}$production are presented for samples in which statistically significant ( $<<0.05$, Student's $t$-test) production or loss was observed. bd: below detection; -:no significant change

\begin{tabular}{|c|c|c|c|c|c|c|}
\hline Site sample & $\begin{array}{c}\text { Control } \\
\text { DPA }(\mu \mathrm{M})\end{array}$ & $\begin{array}{l}\text { Irradiated } \\
\text { DPA }(\mu M)\end{array}$ & $\begin{array}{l}\text { DON norm. } \\
\text { DPA prod. } \\
\times 10^{-3} \mathrm{~h}^{-1}\end{array}$ & $\begin{array}{c}\text { Control } \\
\mathrm{NO}_{2}^{-}(\mu \mathrm{M})\end{array}$ & $\begin{array}{l}\text { Irradiated } \\
\mathrm{NO}_{2}^{-}(\mu \mathrm{M})\end{array}$ & $\begin{array}{l}\text { DON norm. } \\
\mathrm{NO}_{2}^{-} \text {prod. } \\
\times 10^{-3} \mathrm{~h}^{-1}\end{array}$ \\
\hline \multicolumn{7}{|l|}{ Surface water } \\
\hline I. Town Creek & $0.14 \pm 0.07$ & $0.14 \pm 0.08$ & - & bd & bd & - \\
\hline III. Satilla River (RE) & $0.82 \pm 0.04$ & $0.81 \pm 0.10$ & - & $0.24 \pm 0.01$ & $0.24 \pm 0.00$ & - \\
\hline III. Satilla River (UF) & $2.68 \pm 0.07$ & $2.54 \pm 0.08$ & - & $0.63 \pm 0.01$ & $0.56 \pm 0.01$ & $-0.08 \pm 0.02$ \\
\hline III. Umbrella Creek (RE) & $0.30 \pm 0.03$ & $0.34 \pm 0.02$ & - & $0.36 \pm 0.02$ & $0.37 \pm 0.05$ & - \\
\hline III. Umbrella Creek (UF) & $0.66 \pm 0.05$ & $0.66 \pm 0.05$ & - & $0.49 \pm 0.02$ & $0.48 \pm 0.01$ & - \\
\hline \multicolumn{7}{|l|}{ Shallow groundwater } \\
\hline I. Upland GW-A & $0.67 \pm 0.07$ & $0.53 \pm 0.07$ & - & bd & bd & \\
\hline I. Upland GW-B & $1.29 \pm 0.02$ & $1.88 \pm 0.25$ & $1.31 \pm 0.77$ & bd & bd & \\
\hline I. Marsh GW & $1.82 \pm 0.11$ & $1.80 \pm 0.10$ & - & bd & bd & \\
\hline I. Creek GW-A & $1.32 \pm 0.06$ & $1.24 \pm 0.05$ & - & bd & bd & \\
\hline I. Creek GW-B & $1.28 \pm 0.35$ & $1.28 \pm 0.25$ & - & bd & bd & \\
\hline II. Brunswick GW & $0.07 \pm 0.02$ & $0.12 \pm 0.01$ & - & $0.05 \pm 0.01$ & $0.03 \pm 0.01$ & $-1.05 \pm 0.01$ \\
\hline II. St. Simon's GW-A & bd & $0.16 \pm 0.08$ & - & $0.08 \pm 0.00$ & $0.08 \pm 0.01$ & - \\
\hline II. St. Simon's GW-B & $0.14 \pm 0.03$ & $0.22 \pm 0.09$ & - & $0.06 \pm 0.01$ & $0.04 \pm 0.00$ & - \\
\hline II. St. Simon's GW-C & bd & bd & & $0.04 \pm 0.00$ & $0.07 \pm 0.01$ & $0.16 \pm 0.01$ \\
\hline III. Umbrella GW-A (RE) & $1.19 \pm 0.08$ & $0.86 \pm 0.10$ & $-1.61 \pm 0.63$ & $0.09 \pm 0.02$ & $0.09 \pm 0.00$ & - \\
\hline III. Umbrella GW-A (UF) & $2.11 \pm 0.04$ & $1.78 \pm 0.07$ & $-0.6 \pm 0.15$ & $0.23 \pm 0.02$ & $0.24 \pm 0.01$ & - \\
\hline III. Umbrella GW-B (RE) & $0.25 \pm 0.02$ & $0.25 \pm 0.04$ & - & $0.09 \pm 0.02$ & $0.07 \pm 0.00$ & - \\
\hline III. Umbrella GW-B (UF) & $0.48 \pm 0.09$ & $0.37 \pm 0.02$ & - & $0.09 \pm 0.00$ & $0.08 \pm 0.01$ & - \\
\hline
\end{tabular}

water samples and in 1 of the 8 groundwater samples. Photochemical $\mathrm{NO}_{2}^{-}$production $(\mathrm{p}<0.01)$ was also observed in 1 of 8 groundwater samples. Normalized to the concentration of $\mathrm{DON}$ in the samples, $\mathrm{NO}_{2}^{-}$ production and loss rates were low relative to those observed for $\mathrm{NH}_{4}^{+}$and DPA $\left(-1.1 \times 10^{-3},-0.1 \times 10^{-3}\right.$ and $0.2 \times 10^{-3} \mathrm{~h}^{-1}$ ).

The absorbances of samples collected at Site III were compared before and after irradiation to measure the fading of chromophoric DOM caused by exposure to sunlight. In both the rotary evaporation and ultrafiltration treatments, the irradiated groundwater samples were slightly more faded (11 to $12 \%$ ) relative to the fading of irradiated surface water samples (6 to $9 \%$; Table 7). Normalized to either absorbance or DON, the $\mathrm{NH}_{4}^{+}$photoproduction rates of manipulated (Site III) samples indicated the same relative DOM photoreactivity. The greatest rate of $\mathrm{NH}_{4}^{+}$photoproduction was observed in concentrated ultrafiltered tidal creek water, and the loss observed in groundwaters was comparable to, or greater than, production observed in surface waters (Tables 5 \& 7). DOC concentrations were also determined in samples from Site III, but there were no detectable differences in DOC between irradiated and control replicates (not shown).

\section{DISCUSSION}

In this study, 3 primary results were observed. First, there was photochemical $\mathrm{NH}_{4}{ }^{+}$production in surface samples. Second, there was more photochemical loss than photoproduction of $\mathrm{NH}_{4}^{+}$in groundwater

Table 7. Effect of irradiation on the absorbance of samples collected at Site III, the Satilla River Estuary. The light screening factor is a measure of the self-shading of light within a sample by colored dissolved organic matter. Absorbance-normalized $\mathrm{NH}_{4}^{+}$production, corrected for light screening, is also presented for samples in which statistically significant $(\mathrm{p}<0.05$, Student's $t$-test) production or loss was observed. -: no significant change

\begin{tabular}{|lccc|}
\hline Sample & $\begin{array}{c}\text { Fading } \\
350 \mathrm{~nm} \\
(\%)\end{array}$ & $\begin{array}{c}\text { Light } \\
\text { screening } \\
\text { factor }\end{array}$ & $\begin{array}{c}\text { Absorbance- } \\
\text { normalized } \\
\text { production } \\
\left(\mathrm{nM} \mathrm{m} \mathrm{h}^{-1}\right)\end{array}$ \\
\hline Surface water & & & \\
Satilla River (RE) & 8.3 & 0.83 & $0.52 \pm 0.07$ \\
Satilla River (UF) & 7.0 & 0.59 & $0.17 \pm 0.09$ \\
Umbrella Creek (RE) & 6.4 & 0.96 & - \\
Umbrella Creek (UF) & 9.3 & 0.91 & $1.45 \pm 0.63$ \\
Shallow groundwater & & & - \\
Umbrella GW-A (RE) & 11.5 & 0.91 & $-0.98 \pm 0.20$ \\
Umbrella GW-A (UF) & 12.4 & 0.78 & - \\
Umbrella GW-B (RE) & 11.6 & 0.98 & $-2.00 \pm 0.67$ \\
Umbrella GW-B (UF) & 11.8 & 0.95 & \\
\hline
\end{tabular}


samples. Third, consistent photoproduction of DPA and $\mathrm{NO}_{2}^{-}$was not observed. Each of these results is discussed below.

\section{Photochemical production of $\mathrm{NH}_{4}{ }^{+}$in surface waters}

DON in the surface waters of many systems, including the Satilla River, is known to release $\mathrm{NH}_{4}{ }^{+}$when exposed to sunlight (Bushaw et al. 1996, Gao \& Zepp 1998). The results of the present study support that conclusion. Ammonium was photochemically produced in most (4 of 5) river and creek samples and treatments, although photoproduction rates were low in manipulated samples, where $\mathrm{NH}_{4}{ }^{+}$was removed or DON was concentrated. Normalized to DON concentrations, the rate of whole water photochemical $\mathrm{NH}_{4}{ }^{+}$ production observed in the unmanipulated surface water sample $\left(2.9 \times 10^{-3} \mathrm{~h}^{-1}\right)$ was similar to DONnormalized rates of $\mathrm{NH}_{4}^{+}$production observed from Satilla River Estuary fulvic acids and whole water from the Suwanee River $\left(2.5 \times 10^{-3}\right.$ and 2.9 to $4.9 \times 10^{-3} \mathrm{~h}^{-1}$; Bushaw et al. 1996), but less than rates of photochemical production from DOM in a Louisiana Bayou $(12 \times$ $10^{-3}$ to $26 \times 10^{-3} \mathrm{~h}^{-1}$; Wang et al. 2000). Normalized to light absorbance at $350 \mathrm{~nm}, \mathrm{NH}_{4}{ }^{+}$photochemical production in manipulated samples at Site III was also less than absorbance-normalized production rates observed from whole DOM in the Satilla River and from the Louisiana Bayou (Bushaw et al. 1996, Wang et al. 2000).

The low rates of photochemical $\mathrm{NH}_{4}{ }^{+}$production in samples from Site III may have been the result of the experimental manipulations. In a study of $\mathrm{NH}_{4}{ }^{+}$photochemical production from DOM fractions in Bayou Trepagnier, Louisiana, Wang et al. (2000) observed the greatest DON-normalized rate of photochemical $\mathrm{NH}_{4}{ }^{+}$ production from LMW (<1000 Da) DOM. The ultrafiltration treatment used in the present study preferentially removed that LMW DOM. The $\mathrm{NH}_{4}{ }^{+}$removal treatment may have also reduced photochemical $\mathrm{NH}_{4}{ }^{+}$ production in manipulated groundwater samples, in which 13 to $19 \%$ of the DON was lost, possibly due to volatilization of amine $\mathrm{N}$.

\section{Photochemically mediated loss of $\mathrm{NH}_{4}{ }^{+}$in groundwaters}

Statistically significant $(t$-test, $\mathrm{p}<0.05$ ) photochemical production of $\mathrm{NH}_{4}{ }^{+}$from groundwater-derived DON was observed in only 2 of the 13 groundwater samples in this study. This suggests that shallow groundwater DON in these systems, despite limited previous exposure to sunlight, is not more likely to photochemically produce $\mathrm{NH}_{4}{ }^{+}$than surface water DON, as initially hypothesized.

In contrast, the photochemically mediated loss of $\mathrm{NH}_{4}{ }^{+}$was observed in 5 of 13 groundwater samples (Table 5). There are a few potential sinks of $\mathrm{NH}_{4}{ }^{+}$or $\mathrm{NH}_{3}$ in these samples that could explain the observed loss of $\mathrm{NH}_{4}{ }^{+}$(as $\mathrm{NH}_{4}{ }^{+}$and $\mathrm{NH}_{3}$ are in equilibrium at a given $\mathrm{pH}$, a loss of $\mathrm{NH}_{3}$ would lead to the loss of $\mathrm{NH}_{4}^{+}$). First, the loss of $\mathrm{NH}_{4}{ }^{+}$may have been the result of $\mathrm{NH}_{4}{ }^{+}$ oxidation; however, no parallel increase in the concentration of oxidized forms of inorganic $\mathrm{N}, \mathrm{NO}_{3}{ }^{-}$or $\mathrm{NO}_{2}{ }^{-}$ was observed during the experiment. Second, $\mathrm{NH}_{4}{ }^{+}$ may have been volatilized (as $\mathrm{NH}_{3}$ ) due to microscale increases in the concentration of hydroxide produced during the photooxidation of DOM (Stumm \& Morgan 1996). Third, $\mathrm{NH}_{4}{ }^{+}$loss may have been the result of photochemical incorporation of $\mathrm{NH}_{3}$ into DOM. Abiotic, oxidative incorporation of $\mathrm{NH}_{3}$ into DOM has been observed in other systems, including the incorporation of $\mathrm{NH}_{3}$ into triglycerides via a photochemically mediated process (Kieber et al. 1997). Aldehydes and ketoacids, products of the photooxidation of humic substances, also readily form imines from $\mathrm{NH}_{3}$ and DPA, which can hydrolyze abiotically, releasing $\mathrm{NH}_{4}{ }^{+}$ gradually (Cohen \& Ojanpera 1975). Ammonia also appears to react with keto and quinone groups in humic substances, in a process associated with oxidation, and is incorporated into biologically unavailable forms, such as pyrrole and indole N (Thorn \& Mikita 1992). These mechanisms suggest that both biologically available (imines) and biologically unavailable (pyrrole and indole $\mathrm{N}$ ) organic $\mathrm{N}$ forms are sinks for $\mathrm{NH}_{3}$ in the process of photooxidation.

The tendency for $\mathrm{NH}_{4}{ }^{+}$to be lost from photooxidized groundwater samples appeared to be influenced by $\mathrm{NH}_{4}{ }^{+}$concentrations. The concentration of $\mathrm{NH}_{4}{ }^{+}$in many of these samples was high, but this is common in surficial groundwaters in coastal Georgia and South Carolina (Joye et al. unpubl.). A linear regression of the change in $\mathrm{NH}_{4}{ }^{+}$concentration after exposure to light against the initial $\mathrm{NH}_{4}{ }^{+}$concentration indicated that groundwater samples with higher ambient $\mathrm{NH}_{4}{ }^{+}$concentrations lost more $\mathrm{NH}_{4}{ }^{+}$during irradiation (Fig. $2 ; \mathrm{r}^{2}=0.50, \mathrm{n}=12$ ). This suggests that in surface waters with low ambient $\mathrm{NH}_{4}{ }^{+}$concentrations, losses of $\mathrm{NH}_{4}{ }^{+}$due to the photooxidation of this DOM would be slight. In support of this possibility, no photochemical loss of $\mathrm{NH}_{4}{ }^{+}$was observed in the groundwater samples in which $\mathrm{NH}_{4}{ }^{+}$concentrations were experimentally reduced through rotary evaporation (Table 5).

While the photochemical production of $\mathrm{NH}_{4}{ }^{+}$from aquatic DOM has been observed in many studies, the photochemically mediated loss of $\mathrm{NH}_{4}{ }^{+}$has also been observed, generally in non-estuarine waters with 
higher $\mathrm{NH}_{4}^{+}$concentrations $(>1 \mu \mathrm{M})$. In humic-rich river, lake and groundwater samples from the River Öre and Svartberget catchments in northern Sweden, exposure to sunlight slightly reduced $\mathrm{NH}_{4}{ }^{+}$concentrations (Bertilsson et al. 1999). In pasture and forest runoff waters from New Brunswick and Stanton, New Jersey, exposure to sunlight also slightly reduced $\mathrm{NH}_{4}{ }^{+}$ concentrations (Wiegner \& Seitzinger 2001). The abiotic losses of $\mathrm{NH}_{4}{ }^{+}$in groundwater samples exposed to sunlight in the present study were consistent with the abiotic losses of $\mathrm{NH}_{4}{ }^{+}$above and suggest that the source of DON and the ambient $\mathrm{NH}_{4}{ }^{+}$concentration affect the net direction of photochemical $\mathrm{NH}_{4}{ }^{+}$production or loss.

Photochemical losses of $\mathrm{NH}_{4}{ }^{+}$may have important implications for microbial decomposition of DOM at these sites. The irradiation of DOM produces an array of compounds that enhance bacterial production (Moran \& Zepp 1997), of which $\mathrm{NH}_{4}{ }^{+}$is only one. However, $\mathrm{N}$ often limits bacterial productivity in aquatic systems, so the photochemical production or loss of $\mathrm{NH}_{4}{ }^{+}$and other forms of bioavailable $\mathrm{N}$ may have a significant effect on the microbial decomposition of DOM. Ammonium was photochemically produced by the irradiation of fulvic and humic acids from a boreal pond in northern Canada and from rivers and an estuary in the southeastern USA. In samples where the photochemical production of $\mathrm{NH}_{4}{ }^{+}$was observed, a parallel release of bacteria from $\mathrm{N}$ limitation was also observed (Bushaw et al. 1996, Bushaw-Newton \& Moran 1999). In studies where no photochemical $\mathrm{NH}_{4}{ }^{+}$ production or a net loss of $\mathrm{NH}_{4}{ }^{+}$was observed, bacterial productivity was not enhanced (Bertilsson et al. 1999, Wiegner \& Seitzinger 2001).

\section{Photoproduction of DPA and $\mathrm{NO}_{2}^{-}$}

In the present study, the photochemical production of DPA and $\mathrm{NO}_{2}^{-}$were not consistently observed. However, organic matter from the Skidaway River, Satilla River Estuary, and Suwanee Rivers in the southeastern USA and Lake Skärshult in southern Sweden has been shown to release DPA when exposed to sunlight (Jørgensen et al. 1998, Bushaw-Newton \& Moran 1999, Tarr et al. 2001). This release, in addition to the release of $\mathrm{NH}_{4}{ }^{+}$, may increase the productivity of $\mathrm{N}$ limited bacteria as they degrade humic substances. Nitrite is also produced by the photolysis of humic substances (Kieber et al. 1999) and from $\mathrm{NO}_{3}{ }^{-}$by a number of reactions energized by UVB light (Zafiriou \& True 1979). However, $\mathrm{NO}_{2}^{-}$production was observed in only 1 of the 8 irradiated samples in the present study in which $\mathrm{NO}_{2}{ }^{-}$concentrations were above the limit of detection.

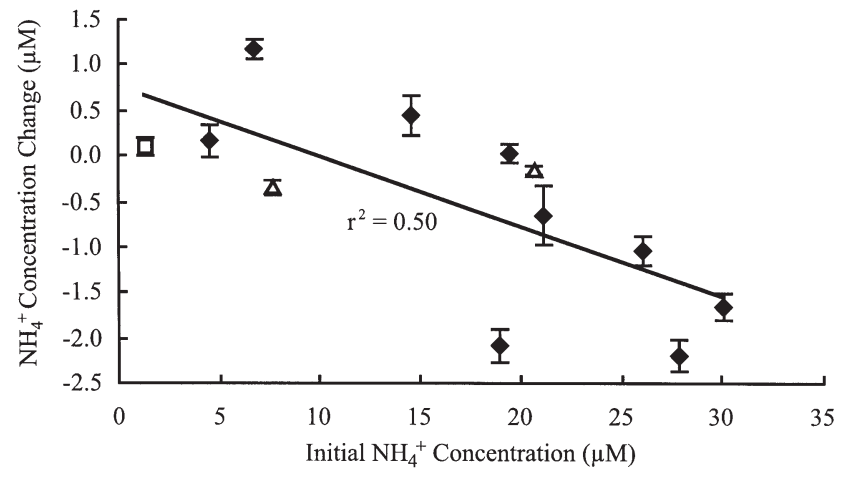

Fig. 2. Change in $\mathrm{NH}_{4}{ }^{+}$concentration after an exposure of unmanipulated $(\diamond), \mathrm{NH}_{4}{ }^{+}$removed $(\square)$, and DON concentrated $(\Delta)$ groundwater samples to natural or artificial sunlight (xenon arc lamp, $1000 \mu \mathrm{E} \mathrm{m} \mathrm{m}^{-2} \mathrm{~s}^{-1}$ ), plotted against the initial $\mathrm{NH}_{4}{ }^{+}$concentration. Means $\pm \mathrm{SD}$ shown, $\mathrm{n}=3$

The lack of consistency in the photoproduction of DPA and $\mathrm{NO}_{2}^{-}$may be due to the relatively low concentrations of DOM used in this study. Both of the photochemical studies mentioned above (BushawNewton \& Moran 1999, Kieber et al. 1999) were conducted on isolated and concentrated humic substances. The higher concentrations of humic substances in those studies may have allowed more consistent detection of the low rates of photochemical production that have been observed.

\section{CONCLUSION}

While the photooxidation of surface water DOM appears to be a source of $\mathrm{NH}_{4}{ }^{+}$to many estuaries, the photooxidation of groundwater DOM at these sites does not appear to be. At high concentrations of $\mathrm{NH}_{4}{ }^{+}$, as in the groundwater samples collected for this study, the photooxidation of groundwater DOM may slightly reduce $\mathrm{NH}_{4}{ }^{+}$concentrations. This finding suggests an additional role for the photooxidation of DOM in the regulation of $\mathrm{NH}_{4}{ }^{+}$concentrations in surface waters. The change in $\mathrm{NH}_{4}{ }^{+}$concentrations in irradiated, unmanipulated groundwater samples ranged from a production of $0.1 \mu \mathrm{M} \mathrm{h}^{-1}$ to a loss of $0.3 \mu \mathrm{M} \mathrm{h}^{-1}$. These rates are low compared to summer rates of biotic $\mathrm{NH}_{4}{ }^{+}$ uptake (1.2 to $1.6 \mu \mathrm{M} \mathrm{h}^{-1}$; Bronk unpubl.) in the Altamaha Estuary, a major estuary between the study sites. During the winter and spring, however, biotic $\mathrm{NH}_{4}{ }^{+}$uptake rates are significantly lower $(0.11$ to $0.12 \mu \mathrm{M} \mathrm{h}^{-1}$ ), only slightly greater than the median rate of loss observed in this study. This suggests that following events that introduce a large volume of groundwater to surface waters, fresh DOM may be a significant sink for $\mathrm{NH}_{4}{ }^{+}$in the near surface, but this effect may be reduced by low $\mathrm{NH}_{4}{ }^{+}$concentrations. 
Acknowledgements. This research was supported by NOAA grant NAO6 RG0029 from Georgia Sea Grant to D.A.B. and NOAA grants NA87OZ0231 and NA97OZ0155 through a Georgia Sea Grant Coastal Management Fellowship to D.J.K. We thank Dr Moran of the University of Georgia and Dr Zepp of the US Environmental Protection Agency for helpful discussions and the use of laboratory equipment. We also thank M. Sanderson of VIMS for assistance with laboratory analyses, Dr Gardner at the University of South Carolina for use of groundwater monitoring wells at North Inlet (NSF EAR9218972), and the University of Georgia Marine Extension in Brunswick, Georgia, for assistance with field work.

\section{LITERATURE CITED}

Aiken GR (1985) Isolation and concentration techniques for aquatic humic substances. In: Aiken GR, McKnight DM, Wershaw RL, MacCarthy P (eds) Humic substances in soil, sediment and water. Wiley, Chichester, p 363-385

Alberts JJ, Filip Z (1994) Humic substances in rivers and estuaries of Georgia, USA. Trends Chem Geol 1:143-162

Alberts JJ, Takács M (1999) Importance of humic substances for carbon and nitrogen transport into southeastern United States estuaries. Org Geochem 30:385-395

Benner R, Biddanda B, Black B, McCarthy M (1997) Abundance, size distribution, and stable carbon and nitrogen isotopic compositions of marine organic matter isolated by tangential-flow ultrafiltration. Mar Chem 57:243-263

Bertilsson S, Stepanauskas R, Cuadros-Hansson R, Granéli W, Wikner J, Tranvik L (1999) Photochemically induced changes in bioavailable carbon and nitrogen pools in a boreal watershed. Aquat Microb Ecol 19:47-56

Bronk DA (2002) Dynamics of organic nitrogen. In: Hansell DA, Carlson CA (eds) Biogeochemistry of marine dissolved organic matter. Academic Press, San Diego, p 153-247

Bronk DA, Lomas MW, Glibert PM, Schukert KJ, Sanderson MP (2000) Total dissolved nitrogen analysis: comparisons between the persulfate, UV and high temperature oxidation methods. Mar Chem 69:163-178

Bushaw KL, Zepp RG, Tarr MA, Schulz-Jander D, Bourbonniere RA, Hodson RE, Miller WL, Bronk DA, Moran MA (1996) Photochemical release of biologically available nitrogen from aquatic dissolved organic matter. Nature 381:404-407

Bushaw-Newton KL, Moran MA (1999) Photochemical formation of biologically available nitrogen from dissolved humic substances in coastal marine systems. Aquat Microb Ecol 18:285-292

Clarke JS, Hacke CM, Peck MF (1990) Geology and groundwater resources of the coastal area of Georgia. Georgia Geol Surv Bull 113

Cohen SG, Ojanpera SJ (1975) Photooxidation of methionine and related compounds. J Am Chem Soc 97:5633-5634

Gao HZ, Zepp RG (1998) Factors influencing photoreactions of dissolved organic matter in a coastal river of the southeastern United States. Environ Sci Technol 32:2940-2946

Gardner WS, Cavaletto JF, Bootsma HA, Lavrentyev PJ, Troncone F (1998) Nitrogen cycling rates and light effects in tropical Lake Maracaibo, Venezuela. Limnol Oceanogr 43: 1814-1825

Garside C (1982) A chemi-luminescent technique for the determination of nanomolar concentrations of nitrate and nitrite in sea-water. Mar Chem 11:159-167

Editorial responsibility: Bess Ward,

Princeton, New Jersey, USA
Grasshoff K (1983) Determination of nitrate. In: Grasshoff K, Ehrhardt M, Kremling K (eds) Methods of seawater analysis. Verlag Chemie, Weinheim, p 143-150

Jørgensen NOG, Tranvik L, Edling H, Granéli W, Lindell M (1998) Effects of sunlight on occurrence and bacterial turnover of specific carbon and nitrogen compounds in lake water. FEMS Microbiol Ecol 25:217-227

Kieber RJ, Hydro LH, Seaton PJ (1997) Photooxidation of triglycerides and fatty acids in seawater: implication toward the formation of marine humic substances. Limnol Oceanogr 42:1454-1462

Kieber RJ, Li A, Seaton PJ (1999) Production of nitrite from the photodegradation of dissolved organic matter in natural waters. Environ Sci Technol 33:993-998

Koroleff F (1983) Determination of ammonia. In: Grasshoff K, Ehrhardt M, Kremling K (eds) Methods of seawater analysis. Verlag Chemie, Weinheim, p 150-157

Liebezeit G, Behrends B (1999) Determination of amino acids and carbohydrates. In: Grasshoff K, Kremling, K, Ehrhardt $\mathrm{M}$ (eds) Methods of seawater analysis. Wiley-VCH, Weinheim, p 541-544

Miller WL, Zepp RG (1995) Photochemical production of dissolved inorganic carbon from terrestrial organicmatter: significance to the oceanic organic-carbon cycle. Geophys Res Lett 22:417-420

Moran MA, Zepp RG (1997) Role of photoreactions in the formation of biologically labile compounds from dissolved organic matter. Limnol Oceanogr 42:1307-1316

Moran MA, Sheldon WM, Sheldon JE (1999) Biodegradation of riverine dissolved organic carbon in five estuaries of the southeastern United States. Estuaries 22:55-64

Parsons TR, Maita Y, Lalli CM (1984) A manual of chemical and biological methods for seawater analysis. Pergamon Press, New York

Seitzinger SP, Sanders RW (1997) Contribution of dissolved organic nitrogen from rivers to estuarine eutrophication. Mar Ecol Prog Ser 159:1-12

Stumm W, Morgan JJ (1996) Aquatic chemistry: chemical equilibria and rates in natural waters. John Wiley \& Sons Inc, New York

Tarr MA, Wang W, Bianchi TS, Engelhaupt E (2001) Mechanisms of ammonia and amino acid photoproduction from aquatic humic and colloidal matter. Water Res 15: 3688-3696

Thorn KA, Mikita MA (1992) Ammonia fixation by humic substances: a N-15 and C-13 NMR-study. Sci Total Environ 113:67-87

Thurman EM (1985) Organic geochemistry of natural waters. John Wiley and Sons, New York

Valiela I, Costa JE (1988) Eutrophication of Buttermilk Bay, a Cape-Cod coastal embayment: concentrations of nutrients and watershed nutrient budgets. Environ Manage 12: $539-553$

Wang WW, Tarr MA, Bianchi TS, Engelhaupt E (2000) Ammonium photoproduction from aquatic humic and colloidal matter. Aquat Geochem 6:275-292

Wiegner TN, Seitzinger SP (2001) Photochemical and microbial degradation of external dissolved organic matter inputs to rivers. Aquat Microb Ecol 24:27-40

Zafiriou OC, True MB (1979) Nitrate photolysis in seawater by sunlight. Mar Chem 8:33-42

Zepp RG (1982) Experimental approaches to environmental chemistry. In: Hutzinger $\mathrm{O}$ (ed) The handbook of environmental chemistry, Vol 2B. Springer-Verlag, New York, p 19-41

Submitted: March 19, 2001; Accepted: November 26, 2001 Proofs received from author(s): January 9, 2002 